\title{
Investigating the Effects of Migrant Remittances on the Economic Growth of Cameroon
}

\author{
Moses A. Ofeh ${ }^{1} \&$ Ali T. Muandzevara ${ }^{2}$ \\ ${ }^{1}$ Department of Economics, Higher Teacher Training College Bambili, University of Bamenda, Cameroon \\ ${ }^{2}$ Government High School, Wabanne-Fontem, Cameroon \\ Correspondence: Moses A. Ofeh, Department of Economics, Higher Teacher Training College Bambili, \\ University of Bamenda, Cameroon. Tel: 237-677-879-520. E-mail: ofeh2002@yahoo.fr
}

Received: December 1, 2016

Accepted: December 25, 2016

Online Published: January 10, 2017

doi:10.5539/ijef.v9n2p58

URL: http://dx.doi.org/10.5539/ijef.v9n2p58

\begin{abstract}
Low and unsteady economic growth rates and strategies for fostering growth are major issues of concern for Cameroon. The paper attempted to investigate the effects of remittances on the economic growth of Cameroon. To achieve the objective for a clearer understanding of the dynamics of migrant remittances in relation to economic growth in Cameroon, the least squares method of multiples regression was exploited to analysze data collected from 1980 to 2013. The results revealed that migrant remittances to the tune of $1.5 \%$ positively but insignificantly explained economic growth in Cameroon.Further, consumption expenditure; government expenditure and exports were found to positively but significantly explain growth while investment expenditure was found to positively but insignificantly determine growth. Only imports alone stood to negatively and significantly influence economic growth in Cameroon.The value of R-squared Adjusted showed that $85 \%$ of variation in GDP was explained by variations in the independent variables specified in the model. Therefore, any policy measure aimed at improving upon the level of economic growth in Cameroon must give consideration to migrant remittances.
\end{abstract}

Keywords: Cameroon, economic growth, migrants, remittances

\section{Introduction}

Migrants, remittances and economic growth are burning issues confronting sending and hosting countries of migrants today due to the influence of migrant's activities in the sending and receiving countries. While some authors view migrants' remittances and related activities as having positive impacts on economic growth, others argue that migrants' remittances do not contribute to economic growth in the recipient countries. In fact, remittance is a new phenomenon in the global financial system because of its size and impact on the world economic systems. Data from World Bank (2011) indicates that global remittance stood at 440.1 billion dollars in 2011 and remittance was $0.31 \%$ of the global GDP in 2009. The microeconomics of remittances has been focused since the early 1980 s on the role of information and social interaction in explaining transfer behaviors. This has led to a change in the way economic researchers look at the determinants of remittances in terms of motives. From a more macroeconomic perspective, new growth theories have also greatly altered the directions for research on the impact of migration and remittances. Previous findings in the 1970s and 1980s were centered on the short run effects of international transfer mainly within the framework of static trade models. Gradually, focus has shifted to long run considerations notably the role of migrant remittances in the dynamics of inequality and growth.

In 2010, officially recorded migrant remittances to developing countries reached \$ 334 billion (World Bank, 2010). According to the United Nations, there were about 214 million international migrants in 2010. In relative terms, this corresponds to over $3 \%$ of the world population. This percentage does not seem exceptionally high, especially when compared to the proportion of other cross boarder transactions such as trade and investment. However, the social and political relevance of migration goes beyond numbers. Migration involves people, not just as production factors but equally the related plans, dreams, frustrations, hopes and interest of the people.

For many developing countries, remittances constitute a large source of foreign income relative to other financial flows. Remittances have shifted seriously to reducing poverty and promoting human development. Evidently, 
this is well documented and often well reported to anchor and influence the overall development process (Ratha, 2007; Das \& Serieux, 2010).

In fact, one of the most conspicuous signs of the process of globalization is the increase in migratory flows among countries. In an increasingly integrated world, people within significant controls move across national borders seeking for greener opportunities on foreign soils.

In general, studies from Asia offer more positive assessments of migrant remittances in promoting development than studies from other regions. This is probably due to three factors.Firstly, studies in Asia have endeavored more to measure and assess the indirect effects of remittances rather than focusing solely on direct effects that are the remittances themselves. Secondly, many Asian countries notably Korea, Thailand, and Indonesia have implemented macroeconomic policies favorable to market development. Finally, several Asian governments have implemented specific policies and strategies to encourage the repatriation of foreign earnings and capture remittances for the purpose of development. (Athukorala, 1993).

There is a growing debate on how migrants' remittances are used and to what extent they contribute to the migrant's country of origin (Ratha, 2003). Developed countries serve as the origin of total remittances, with the United States of America playing the leading role. It is believed that remittances from south-south are important and even from north-south flows but one thing is certain about this which is the pacity of data.

Geographic barriers are pushed aside, distances are shortened by modern means of communication, and alternative ways of life are shared and presented as desired. All of these have facilited migration. In recent times the direction of movement is gradually reversing from the developed to the developing in search for virgin nature and its pleasantries.

The concrete reason for most households in Cameroon to have someone abroad so that they can lean on for remittance help is finance (Baye, 2005). Locally and prestigiously, those abroad in Cameroon are called 'Bush-fallers'. Remittances as part of GDP of 2008 in Cameroon were $0.8 \%$ and since 2001 migrant remittances have experienced considerable increase. The estimates of the World Bank in 2009 indicated that migrants remittances to Cameroon as from 2000 were 11million US dollars, 103 million US dollars in 2004 and 167million US dollars in 2008. The World Bank ranked Cameroon among the top 10 recipients of remittances within the group with estimated remittance of 0.1billion US dollars (World Bank, 2011). It is difficult to evaluate the real value of migrant remittances on Cameroon economic growth since most remittances are sent informally. At the same time, migration entails brain-drain that hinders economic growth (Berry \& Soligo, 1969, and Rivera, 1982). Also the real impact of migrant remittances on Cameroon's economy could be minimized by volatile exchange rates and domestic inflation. Considering the many growth challenges face by Camerooons, the main objective of the paper is to access the effects of migrants' remittances on the economic growth of Cameroon.

\section{Literature Review}

Concepts on remittances are varied. The World Bank's definition considers remittances to include workers' remittances, compensations of employee, migrant transfers, all of which are obtained from the balance of payment accounts of receivers and remitters. The international monetary fund considers remittances by excluding the "transfers of migrants" as it claims are in most cases unrelated to remittances and hence misleading. Simply, transfers of migrants refer to capital transfers of financial assets made by migrants as they move from one country to another and stay for more than one year. Remittances are money sent by migrant workers in foreign countries to countries of origin. This means, remittances include monetary and non-monetary items sent back home to their families by migrants (Berhane, 2005).

The motives for sending money home by immigrants can broadly be classified into two: altruism and self-interest motives. These two classifications can be further broken down into: altruism, exchange, insurance, investment, inheritance and strategic motives of which can be added education level of migrant, time passed abroad and gender.

The fundamental reason why money is sent home is altruism. According to Lopez Cordova and Olmedo (2006) and Sandhya Mahapatro et al. (2015), it is a situation in which the transfer does not entail any present or future compensation nor does it represent payment for any past debt. According to Lucas and Stark (1985), the remitter derives utility from the well-being of recipients at home and that the amount of remittance and the income are negatively violated. Those that support this theory include Chipeta and Kachaka (2004) who suggested that altruistic motives were behind remittance in Malawi. The reasons for altruistic behavior of remitter may be to mitigate poverty, low income shocks, drought, which affects wellbeing of the family. Most papers have found evidence consistent with altruism behavior, but Lucas and Stark (1985) and Agarwal and Horowitz (2002) have 
considered altruism against alternate family arrangements. Lucas and Stark found evidence in favor of self-interested behavior in Botswana while Agarwal and Horowitz found evidence in favor of altruism in Guyana.

Another reason for remittance is the exchange motive and it involves sending money for services rendered which may involve taking care of the children of migrated persons, housing properties, and repayment of loans borrowed by emigrants to cover emigration cost or education (Prabel \& Dilip, 2012; Kwabena et al., 2014). This is in agreement with the study of Cox et al. (1998) that surveyed households in Peru, and found evidence consistent with the exchange motive for migrant remittances. The exchange motive was theorized as displaying a three waves shape. In the first stage, remittances are assumed to be repayments for informal and implicit loans contracted by migrants for investment in education and migration cost. In the second stage, they are loans made by migrants to young relatives to finance their education until they are themselves ready to migrate (Rose Taylor, 2015; Hasan, 2015). In this light, the amount remitted is expected to diminish in aggregated numbers because not all migrants are expected to give a loan to family members. Thirdly, before returning to country of origin, migrants invest accumulated capital at home, therefore the amount of remittances increase (Mausumi, 2015). Latter the next generations of emigrants repay the loan to the former emigrant lender who may have retired in the home country. Given the nature of the loan, remittances cannot consequently be reduced over time.

Investment is held as another reason for migrant remittances. The migrant may send money for the purchase of land, house or financial assets or start a small business in his/her country because he/she knows the local market more than the current host country. According to Ruiz-Arranz (2006); Emmanuel (2013) remitted funds are particularly used for investment where the financial sector does not meet the credit needs of local entrepreneurs. There are many evidences from various studies on the use of remittances for investment purpose. The investment motive directly translate growth (Gyan, Mukti, \& Kamal, 2011); Asu Siddigue et al. (2012) The study of Woodruff and Zenteno (2001) in Mexico revealed that about one fifth of the capitals invested in 6000 micro enterprises in urban Mexico were financed by remittances. Yang (2008) suggested that households in Philippines that received remittances and benefited from exchange shocks spent more hours in self-employment and were more likely to start capital intensive entrepreneurial enterprises. The survey of 112 Nigerian migrant households in Chicago and a matched sample of 61 families in Nigeria by Osili (2004) found that a third of remittances were spent on housing investment in the preceding years.

Remittances are also emitted for insurance motives. Here, migrants and the remitter household members can enter into some contract wherein migrants would insure shortfalls in their incomes. Such arrangements are encouraging because government sponsored social insurances are generally poor or non-existent according to Yan and Choi (2005); Richard (2011). Also, the rural areas are exposed to risk of crop failure, price fluctuations, insecurity of land tenancies, livestock diseases and inadequate agricultural wages as Stark and levhari, (1982) put it. And so there is need for such contracts wherein migrants intend to insure the farmers left behind in order to neutralize the effects of bad yield or harvest. This was in line with funds sent by migrants in assisting to keep children in school in Ecuador during periods of distress caused by adverse shocks as in the opinion of Calero et al. (2009). Remittances quickened disaster recovery and reconstruction after a devastating earthquake in Pakistan in 2005 .

Migrant remittances may also be motivated by inheritance. Schrieder and knerr (2000) carried out a study in Cameroon and asserted that the reasons for remittances were to keep a reasonable inheritance. In the Republic of Dominican, Dela Briere et al. (2002) suggested that remittances were conditioned by future inheritance.

The migrant's saving motive is also a fertile reason for remittances. Here, the assumption is that the migrant has the intention to return home with a certain amount of savings -the saving target. Thus, remittance flows during the migrant's stay abroad result from a bargaining process between the migrant and his or her family. The claim of migrant family left at home on the migrant income is considered as the demand side and the ability of migrant to remit as the supply side. Therefore the expectation of future incomes are continuously being revised and a nexus of interrelated factors are adjusted including the length of stay, the intensity of work, and the flow of remittances for the family's consumption. On the other hand, the family is regarded as having as its goal an income (including remittances) larger than that of the neighbors, in order to justify the decision to send some family members abroad. Therefore in Cameroon and elsewhere many unorthodox means such as artificial marriages, diplomatic imunities, under the canopy of an influential person, leapping without looking and others have been used to get family members abroad ('Paris at all cost', for leaving Cameroon for France). Empirical evidence for the support of saving target hypothesis was found for Greek-German migration in the period 1960-1982 and for migration from seven Mediterranean countries (Algeria, Egypt, Jordan, Morocco, Syria, Tunisia and Turkey), the remittances being positively correlated to the per capita income in the host as well as in 
the home country (Glytsos et al., 1998, 2002).

Lucas (2004) and Ozge Bilgili et al. (2015) summarized the answers to the question whether migration for permanent settlement resulted in lower remittances than temporary migration. Temporary migrants might have higher incentives to remit to those left behind than permanent migrants according to Galor and Stark (1990). It is discovered that, the longer migrants stay abroad, the lesser are the bonds to the sending economy and the lower are the remittances. Also, if migrants are better paid, they will leave longer in the destination countries. Thus, they could (if they wish) remit more, Lucas therefore, concluded that remittances may initially rise, and eventually decline with duration of stay which may suggest an optimal length of stay to maximize migrants' remittance flows in order to balance greater earning powers against diminishing attachments.

\subsection{Transmission Modes of migrants' Remittances in Cameroon}

Most remittances are made in the form of money. To a much lesser extent, they take the form of goods (such as staple foods or electronic items) or services (religious ceremonies or airline tickets). The focus of our study is on the financial infrastructure for money transfers. Other modes of remittances are touched on to remind readers of the demand for non-financial remittance services. Remittance channels are classified into two categories being the formal and informal.

Formal channels include money transfer services by banks and non-bank financial institutions such as foreign exchange bureaus and dedicated money transfer operators (MTOs), the best known of which are Western Union and Money Gram. The vast majority of MTOs transactions in Camroon are receipts of funds. Information concerning cross-borders money flows is only available on funds sent through formal channels. According to the IMF balance of payments statistics year book (2008), the total value of remittances transmitted through formal arrangements globally was estimated at US $\$ 433$ billions. Russell (1996) and Taylor (1999) observed that less than $50 \%$ of remittances passed through formal channels. Micro-level field studies indicated that clandestine or in-kind transfers were substantial (Lozano, 1993; Massey \& Parrado, 1994).

Informal channels of remittance transfers in Cameroon are similar to those found in other countries. The similarities are probably due in part to the long standing trade and migration links between these countries and Africa (El-Qorchi et al., 2002). It is still very common to send money with friends, relatives, drivers of taxis or buses or to carry it oneself. Other informal systems are modeled on hawala or hundi services or are single destination services provided by individual business people. Indian Diaspora and Somalia refugee's communities in East Africa for example have long had such systems. In Eastleigh a neighborhood of Nairobi known as "Mogadishu", informal agents with radios or satellite phones in Somalia operate money transfer businesses at home (Omer, 2002, Kabucho et al., 2003). Informal channels are common in Cameroon due to weak formal financial infrastructures and lack of access to financial services especially in rural and low income populated areas in Cameroon.

\section{Methodology}

\subsection{Model Specification}

Based on the main objective of the paper, a multiple regression model, linear in parameters $\left(\beta_{\mathrm{i}}\right)$ was used to express the relation among the concerned variables as in equation 1 below.

$$
\log G D P_{t}=\beta_{o}+\beta_{1} \log C_{t}+\beta_{2} \log I_{t}+\beta_{3} \log G_{t}+\beta_{4} \log X_{t}+\beta_{5} \log _{t}+\beta_{6} \log R e m_{t}+U_{t}
$$

Where $\mathrm{t}=$ time, $\log \mathrm{GDP}=$ natural $\log$ of Gross Domestic Product used as a proxy for economic growth, $\log \mathrm{C}=$ natural $\log$ of consumption expenditure, $\log \mathrm{I}=$ natural $\log$ of investment, $\log \mathrm{G}=$ natural $\log$ of government expenditure, $\log X=$ natural $\log$ of export, $\log M=$ natural $\log$ of import, $\operatorname{LogRem}=$ natural $\log$ of migrants' remittances, and $\mathrm{Ut}=$ Stochastic error term . The aprior expectations of the model are such that: $\beta_{\mathrm{o}}>0$ and $\beta_{\mathrm{i}}>0$.

\subsection{Estimation Technique}

Graphs are used to express the trends of the variables and descriptive tables are used to figure out central tendencies information as well as deviations in the data collected. Pairwise correlation matrix is used to inform on the relationship among the variables specified in the model.The OLS technique; because of its BLUE property is therefore exploited to estimate the parameters of the model.

The parameters of the model are acknowledged and validated on the basis of economic, statistic and econometric conventional criteria that go respectively with value and sign of estimated parameters, the t-statistics and p-values to justify whether the coefficients of the parameters are significant; and the stationarity of the series to detect the presence of multicollinearity, autocorrelation and heteroscedasticity. 


\section{Presentation and Discussion of Results}

\subsection{Trend Analysis Results}

The graphical analysis of the data collected allows for an understanding of the nature of the trend of the major variables (GDP and remittances) over the time period. This is to find out whether the variable has a stochastic, deterministic or linear trend as well as whether the variable trends with or without drift.

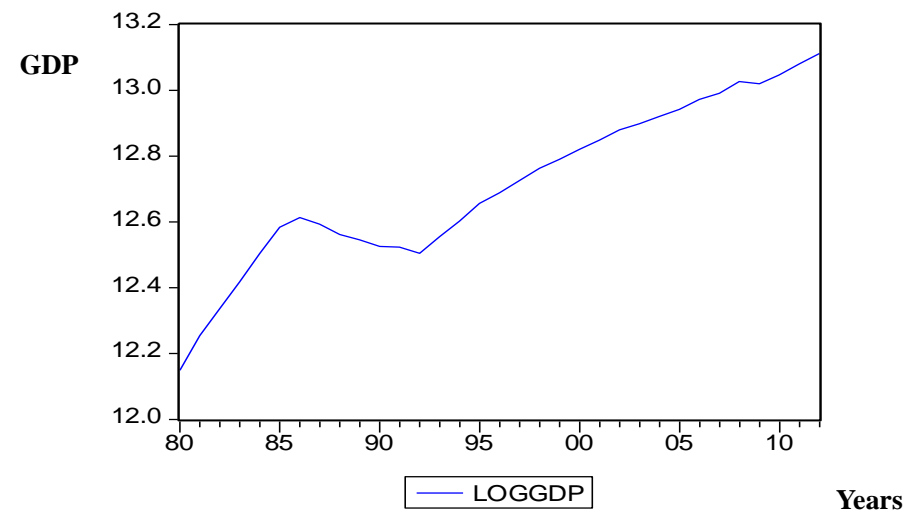

Figure 1. Trends of GDP in Cameroon from (1980-2012)

Source: Computed by Authors using E-views 5.0.

The GDP in Cameroon over the 33 years period shows that the trend is positive and more deterministic since the trend is almost linear, though there was a sharp increase and a subsequent decline in the 80 s. The trend has a positive drift as the value for GDP in 1980 which is the start year is positive. Relating the trend with economic happenings in Cameroon, we discovered that from 1980, there was a steady rise in GDP in Cameroon; which clearly reflected the period of good economic performance attributed to the oil boom of the late $70 \mathrm{~s}$ and subsequent inheritance in the early 80s. The downward sloping nature of the curve of GDP in the late 80s reflected the economic crisis of the late 80s experienced in Cameroon. The low economic performance continued and became worst in the early 90s when the structural adjustment program (SAP) of the World Bank was adopted as a panasea to reverse the dwelling economy. The economy of Cameroon took back a positive growth trend around 1994 which reflected the period when Cameroon joined the Heavily Indebted Poor Countries (HIPC) initiatives of the World Bank. Since the mid 90s, Cameroon has witnessed a low but positive growth trend.

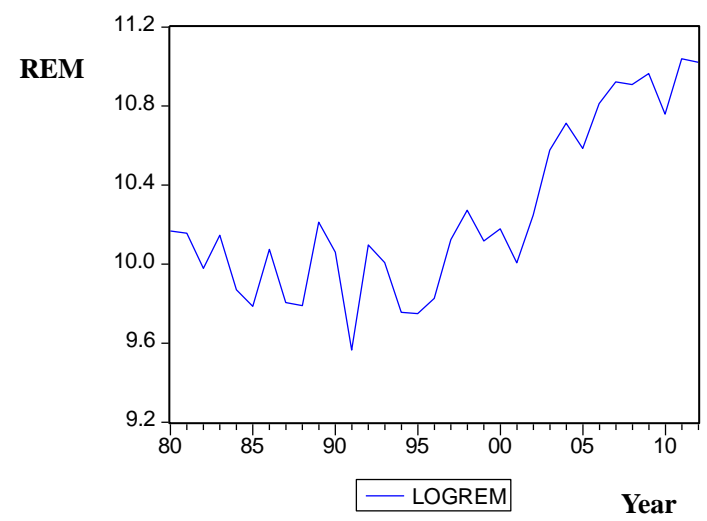

Figure 2. Trends of workers remittances in Cameroon trom (1980-2012)

Source: Computed by Authors using E-views 5.0.

Going by the trend of remittances in Cameroon, we discovered that the trend was positive with a positive drift. However, the trend revealed a series of shocks or fluctuations making predictions about the future level of remittances pretty difficult. The stochastic nature showed that the lowest annual receipts of remittances were recorded in 1991 and the highest in 2011. The trends of the other variables considered in the paper generally have had upward tendencies but exhibiting various degrees of variations depending on the econonomic events in Cameroon for the time frame (see Appendix 1). 


\subsubsection{Descriptive Analysis}

Table 1. Descriptive analysis

\begin{tabular}{lccccccc}
\hline & LOGGDP & LOGC & LOGINV & LOGG & LOGEXP & LOGIMP & LOGREM \\
\hline Mean & 12.71 & 12.55 & 11.97 & 11.75 & 9.46 & 9.52 & 10.25 \\
Median & 12.69 & 12.54 & 11.96 & 11.68 & 9.40 & 9.46 & 10.15 \\
Maximum & 13.11 & 12.96 & 12.40 & 12.25 & 9.87 & 9.93 & 11.04 \\
Minimum & 12.15 & 11.99 & 11.47 & 11.14 & 9.26 & 9.27 & 9.56 \\
Std. Dev. & 0.25 & 0.26 & 0.23 & 0.29 & 0.18 & 0.18 & 0.43 \\
Skewness & -0.22 & -0.21 & -0.02 & -0.04 & 0.85 & 0.78 & 0.53 \\
Kurtosis & 2.28 & 2.13 & 2.12 & 2.46 & 2.42 & 2.47 & 2.07 \\
Jarque-Bera & 0.97 & 1.28 & 1.06 & 0.40 & 4.41 & 3.73 & 2.72 \\
Probability & 0.62 & 0.53 & 0.59 & 0.82 & 0.11 & 0.15 & 0.26 \\
\hline Observation & 33 & 33 & 33 & 33 & 33 & 33 & 33 \\
\hline
\end{tabular}

Source: Computed by Authors using E-views 5.0.

The descriptive analysis table 1 shows the main variables of the study (GDP and remittances) and the others. From the analysis, the mean value of the log of GDP over the period under study is 12.71 with a median of 12.69. The maximum amount of the log of GDP over the period is 13.11 with a minimum of 12.15 and a standard deviation of 0.25 . The Log of GDP is leftly skewed over the period. On the other hand, the maximum amount of the $\log$ of remittances over the period is 11.04 with a minimum of 9.565 and a standard deviation of 0.43 . The Log of remittances is rightly skewed over the period. The statistics about the other variables are glearing from the table.

Most economic time series data are non-stationary and to avoid the situation with such data that can lead to spurious analysis and wrong predictions (Ahmed, 2010), we engaged all the necessary tests to take care of correlation, stationarity and heteroscedasticity (see Appendices 2 for correlation, 3 for stationarity and 4 for multicolinearity).From the correlation matrix table in Appendix 2, it was realised that all the diagonals are 1. This means that there exists a perfect positive correlation between each variable and itself. All the other values of correlation in the table showed very strong positive relationships between the variables .For stationarity of the variables, the Augmented Dickey-Fuller test was carried out and the results are presented in Appendix 3. The results of the ADF test showed that all the variables are non stationary at level which is very common with macroeconomic time series and hence the existence of a unit roots. However, they all achieved stationarity after first difference as all the ADF test statistics were more negative than their critical counterparts at $10 \%$ level of significance. This allowed us to run the regression normally.

\subsection{Regression Analysis}

Table 2. Regression analysis results

\begin{tabular}{|c|c|c|c|c|}
\hline \multicolumn{5}{|c|}{$\begin{array}{l}\text { Dependent Variable: D (LOGGDP) } \\
\text { Method: least Squares } \\
\text { Sample (adjusted): } 19812012 \\
\text { Included observations: } 32 \text { after adjusting endpoints }\end{array}$} \\
\hline $\begin{array}{c}\text { Variable } \\
\end{array}$ & Coefficient & Std. Error & t-Statistic & Prob. \\
\hline $\mathrm{D}(\mathrm{LOGC})$ & 0.68 & 0.09 & 7.81 & 0.00 \\
\hline $\mathrm{D}($ LOGINV) & 0.08 & 0.05 & 1.46 & 0.15 \\
\hline $\mathrm{D}($ LOGG $)$ & 0.19 & 0.07 & 2.66 & 0.014 \\
\hline D(LOGEXP) & 0.17 & 0.06 & 2.75 & 0.01 \\
\hline D(LOGIMP) & -0.17 & 0.06 & -2.90 & 0.01 \\
\hline 4hj'D(LOGREM) & 0.01 & 0.01 & 1.39 & 0.18 \\
\hline $\mathrm{C}$ & 0.00 & 0.003 & 0.24 & 0.81 \\
\hline R-squared & 0.88 & Mean dependent var & & 0.03 \\
\hline Adjusted R-squared & 0.85 & S.D. dependent var & & 0.03 \\
\hline S.E. of regression & 0.01 & Akaike info criterion & & -5.70 \\
\hline Sum squared resid & 0.00 & Schwarz criterion & & -5.38 \\
\hline Log likelihood & 98.27 & F-statistic & & 31.27 \\
\hline Durbin-Watson stat & 2.12 & Prob (F-statistic) & & 0.00 \\
\hline
\end{tabular}

Source: Computed by Authors using E-views 5.0. 
From the regression results in Table 2, the coefficient of consumption is 0.69 , being positive meaning that there exists a positive relationship between consumption and economic growth. This conforms to our apriori theoretical expectation of the coefficient. In this connection, a 100 percentage increase in consumption expenditure will lead to a 68.31 percent increase in GDP in Cameroon with a standard deviation of 0.09. The $\mathrm{p}$-value of consumption expenditure shows that the test is significant even at $1 \%$ level of significance. Therefore, we reject the null hypothesis and consider consumption expenditure to significantly affect economic growth in Cameroon.

With investment expenditure, results show that there exists a positive relationship between investment expenditure and GDP in Cameroon. This is confirming to the apriori theoretical expectations. Specifically, the coefficient shows that a $100 \%$ increases in investment expenditure will lead to $7.9 \%$ increase in GDP with a standard deviation of 0.05 . The p-value of investment expenditure shows that the test is insignificant even at $10 \%$ level of significance. Thus we fail to reject the null hypothesis meaning investment expenditure in Cameroon does not significantly affect economic growth in Cameroon. The insignificant results may be as a result of the fact that most investments in Cameroon are public which are characterised with inefficiency and mismanagement, thus not yielding the desired effects on economic growth. More so, the coefficient of government expenditure is 0.19 and it is positive showing a positive relationship between government expenditures and economic growth in Cameroon as expected. The coefficient shows that a $100 \%$ increase in government expenditure will lead to $18.6 \%$ increase in GDP. The p-value of government expenditure is significant at $5 \%$ level of significance which allows for the rejection of the null hypothesis meaning government expenditure in Cameroon significantly affects economic growth.

The positive coefficient of exports, 0.17 from the results shows that, there exist a positive relationship between exports and GDP in Cameroon. This is in conformity with our expectations about exports. Precisely, the magnitude of the coefficient shows that a $100 \%$ increase in exports will lead to a $16.61 \%$ increase in GDP. The p-value of exports is significant at 5\%, giving us the platform to reject the null hypothesis and hence the conclusion that exports significantly affects economic growth in Cameroon.The results equally show a negative relationship between imports and economic growth in Cameroon $(-0.17)$. This contracts the expectations. Precisely, a $10 \%$ in crease in import is capable of reducing economic growth in Cameroon to the tune of $1.6 \%$. The p-value of the coefficient of imports is significant even at $1 \%$ level of significance and this permits a rejection of the null hypothesis and hence imports negatively and significantly affect economic growth in Cameroon. This is evidently true as more imports, above all consumables allows for outflow of currency, dampening exports and domestic production.

Finally the coefficient of migrant workers remittances is 0.01 which is positive portraying a positive relationship between remittances and economic growth. This is in conformity with the stated expectations about remittances. The coefficient shows that a $100 \%$ increase in remittances is capable of inducing GDP in Cameroon to the value of $1.45 \%$. However, the p-value of remittances is insignificant even at $10 \%$ level of significance. Thus we fail to reject the null hypothesis showing that remittances do not significantly affect economic growth in Cameroon.

The coefficient of the R-squared Adjusted is 0.85 showing that more than $85 \%$ of variations in GDP were caused or explained by variations in the independent variables specified in the model. This means that there was a goodness of fits in our analysis. Also, the p-value of the F-statistic revealed that the model was overall significant at even $1 \%$ level of significance, which buttressed that the results were $99 \%$ reliable.

The DW statistics was 2.12 which when taken to the DW table, it felt in the region of no autocorrelation hence absence of autocorrelation in the analysis.To further validate the analysis, the Breusch-Pagan, Cook-Weisberg test for heteroskedasticity showed an insignificant $\mathrm{Chi}^{2}$ probability even at $10 \%$ (see Appendix 4).This implies that we fail to reject the null hypothesis thus concluding that there is constant variance in our analysis. This means there was the absence of heteroskedasticity (or the presence of homoskedasticity) in the analysis which further validated our predictions.

\section{Summary of Findings, Recommendations and Conclusion}

\subsection{Summary of Findings}

In the paper, we set out to investigate the effect of migrant remittances on the economic growth of Cameroon. In order to achieve the objective, other macro economic variables that prior studies have considered to influence economic growth were included in the model. In order to confirm the relationship and the effects of migrant remittances on the economic growth of Cameroon, correlation analysis, regression analysis and other econometric tests were conducted on the macroeconomic variables data collected. Consumption expenditure, government expenditure, and exports and were found to positively and significantly influence economic growth 
in Cameroon while investment expenditure and migrants' remittances on the other hand were found to positively but insignificantly influence economic growth in Cameroon. Only imports negatively and significantly influence economic growth.

However, any policy measure aimed at improving upon the level of economic growth in Cameroon must take into consideration the effect of migrants' remittances and investment expenditure since they have the correct apriori expectation signs.

\subsection{Recommendations}

The government should increase her expenditure on major infrastructures like roads, schools, hospitals, sea ports, payment of salaries, social securities like pension and family allowances; all considered government expenditure capable of positively influencing economic growth. Cameroonian entrepreneurs should be encouraged to exploit the world market by penetrating with domestic goods to keep exportation above importation. Cameroonians in the Diaspora should be encouraged not only to remit more funds but to transfer the acquired knowledge and technologies back home. They should also be advised to set up cottage industries in Cameroon for the teeming unemployed youths. Also, there is need for prudence in the management of funds sent home by migrants. Such monies are expected to be channeled into productive ventures and not for profligacy. In addition to the above, Cameroon can have the full benefit of improved migrants' remittances under a globalized world economy by creating an investment climate that is favourable to foreign investors and Cameroonians in the Diaspora.

\subsection{Conclusion}

In this study, we have developed a model for examining the effects of migrants' remittances on the economic growth of Cameroon. Four out of the six explanatory variables via Consumption expenditure, Government expenditure and Exports have been found to exert a significant positive effect on economic growth in Cameroon. Migrants' remittances and Investment expenditure turned out to contribute positively but insignificantly to economic growth in Cameroon while only imports have shown a significant negative effect, contrarily to expextations.

\section{References}

Agarwal, R., \& Horowitz, A. (2002). Are International Remittances Altruism or Insurance? Evidences from Guyana using multiple-migrant households. World Development, 30(11), 2033-2044.

Ahmed, B. (2010). Testing Non-Stationarity in Selected Macroeconomic Series from Sudan. African Journal of Economic Policy, 17(2).

Asu Siddigue et al. (2012). Remittances and Economic growth: Empirical Evidence from Bangladash India and Sri Lanka. Journal of Development Studies.

Authokorala, P. (1993). Improving the contribution of migrants' remittances to development, the experience of Asian labor-exporting countries. International Migration, 31, 103-124.

Baye, M. F. (2005). Structure of Sectoral Decomposition of aggregate poverty changes in Cameroon. Paper presented at the international conference on shared Growth in Africa-Accra (pp. 21-22). Organized Cornell University/ISSR/The World Bank.

Behane, T. (2005). Remittances as a tool for Development and Reconstruction in Eritria: An Economic Analysis. Journal of Middle Eastern Geopolitics, 1(2), 21-32.

Berry R. A., \& Soligo, R. (1969). Some welfare aspects of international migration. Journal of Political Economy, $77,778-794$.

Calero et al. (2009). Remittances, Liquidity constraints and Human Capital Investment in Ecuador. World Development, 3716, 1143-1154.

Clipeta, C., \& Kachaka, W. (2004). The Role of migrants Remittances in an Unstable Lower Income Economy, A Case Study of Malaxui. Report Submitted to the Global Development Network, Washington DC USA.

Cox D. et al. (1998). Motives for Private Transfer over the Life- cycle, An Analytical Framework and evidence from Peru. Journal of Development Economics, 55, 57-80.

Das, A., \& Serieux, J. (2010). Remittance and Reverse Flows in Developing Countries. IDEAS Working paper series No 02/2010.

El-Qorchi, M., Samuel, M., \& John, F. W. (2002). Hawala; How does this formal funds transfer system work, and should it be regulated? Finance and Development, 39(4). International monetary Fund, Washington DC. 
Emmanuel, K. K. C. (2013). Remittances, Investment and Growth in Sub-Saharan Africa. Journal of International Trade and Economic Development, 22(7).

Galor, O., \& Stark, O. (1990). Migrants' Savings, the Probability of return migration and migrants' performance. International Economic Review, 31, 463-467

Glytsos et al. (1998, 2002). Migrants' Remittances in the MENA Region, Issues and Policies for Consideration Forum. Newsletter of the Economic Research Forum for the Arab Countries, Iran and Turkey, 5(1), May.

Gyan, P., Mukti, U., \& Kamal, U. (2011). Remittances and Economic Growth in Developing Countries. The European Journal of Development Research, 20(3).

Hasan, M. (2015). Impact of the Destination State on Migrants' Remmitances: A study of remitting among Bengladeshi Migrants in the USA, the UAE and Japan. Migration and Development, 5(1). http://dx.doi.org/10.1080/21632324.2015.1022007

Kabbbucho, K., \& Sander, L. et al. (2003). Pasing the Buch, Money Transfer Systems: The Practice and Potential for Products in Kenya, Nairobi, Micro Save-Africa. Retrieved from http://www.livelihoods.org/hot_topics/docs/RemitKenya pdf

Kwabena, G. B. et al. (2012). Remittances and Investment in Education: Evidence from Ghana. Journal of International Trade and Economic Development.

Lopez, C. E., \& Olmedo, A. (2006). International remittances and development, existing evidence, policies and recommendations preliminary version. WTALLIITD Occasional Paper Series, No. 41.

Lozano, A. F. (1993). Bringing it Back Home: Remittances to the United States. Monograph 37, Center for U.S. -Mexican studies, University of California at San Diego.

Lucas, R. E. B., \& Stark, O. (1985). Motivation to Remit: Evidence from Botswana. Journal of Political Economy, 93(5), 901-18.

Lucas. (2004). International Migration to High Income Countries, some consequences for Economic Development in the sending Countries. Mimeo, Boston University.

Massey, D. S., \& Parrado, E. (1994). Migradollars: The Remittances and Savings of Mexican Migrants to the United States. Population Research and Policy Review, 13, 3-30.

Mausumi, M. (2015). Migration, Development and Welfare: Findings from a Household survey in two selected Villages in Bagladash. Migration and Development, 5(3). http://dx.doi.org/10.1080/21632324.2015.1053304

Omer, A. S. (2002). Supporting systems and procedures for the effective regulation and monitoring of Somali remittance Companies (Hawala). United Nations Development Programme, Somalia.

Osili, U. O. (2004). Migrant and House Investment, Theory and Evidence from Nigeria. Economic Development and Cultural Change, 52(4), 821-50.

Ozge, B. et al. (2015). To return permanently or to return temporarily? Explaining migrants' intentions. Migration and Development, 6, 20.

Prabal, K. D., \& Dilip, R. (2012). Impact of remittances on household income asset and humancapital: Evidence from SriLanka. Migration and Development. http://dx.doi.org/10.1080/21632324.2012.719348

Ratha, D. (2003). Workers remittances, an important and stable source of external development finance in World Bank, Global development finance. Striving for Stability in Development Finance, 1, 157-75.

Ratha. (2007). Leveraging remittances for Development, Migration Policy Institute. World Bank, Washington DC.

Richard, H., \& Adams, J. R. (2011). Evaluating the Economic Impact of International Remittances on Developing Countries Using Household Survey: A literature review. Journal of Development Studies.

Rivera-Batiz, F. L. (1982). International Migration, non- traded goods and economic welfare in source country. Journal of Development Economics, 11, 81-90.

Rose Taylor, S. (2015). The Role of Migrants' networks in Global migration Governance and Development. Migration and Development, 5(3). http://dx.doi.org/10.1080/21632324.2015.1068504

Ruiz Arranz, M. (2006). Boosting Economic Growth. Institute of Development Studies.

Russel, \& Taylor. (1999). The New Economic of Labour Migration and the role of remittances in the migration 
process. International Migration, 37(1), 63-88.

Sandhya, M. et al. (2015). Remittances and Money expenditure Patterns in India and Selected State. Migration and Development. http://dx.doi.org/10.1080/216322324.2015.1044316

Schriender, G., \& Knerr, B. (2000). Labour Migration as a Social Security Mechanism for Small Households in sub-Saharan Africa: The case of Cameroon. Oxford Development Studies, 28(2), 223-236. http://dox.doi.org/10.1080/713688309

Stark, O., \& Levhari, D. (1982). On migration and Risk in LDCs. Economic development and Cultural Change, 31, 191-6.

Taylor, J. (1999). The New Economic of labour Migration and the role of remittances in the migration process. International Migration, 37(1), 63-88.

Woodruff, C., \& Zenteno, R. (2001). Remittances and Micro-Enterprises in Mexico Mimeo. University of California at San Diego.

World Bank. (2011). Migration and Remittance Fact Book. Washington DC.

Yang, D. (2008). International Migration Remittances and Households Investment: Evidence from Philippines, Migrants Exchange Rate Shocks. Economic Journal, 591-630.

Yang, D., \& Choi, H. (2005). Are Remittances Insurance? Evidence from Rainfall Shocks in the Philippines. University of Michigan School of Public Policy, Department of Economics Discussion Paper 53.

\section{Appendix}

\section{Appendix 1}

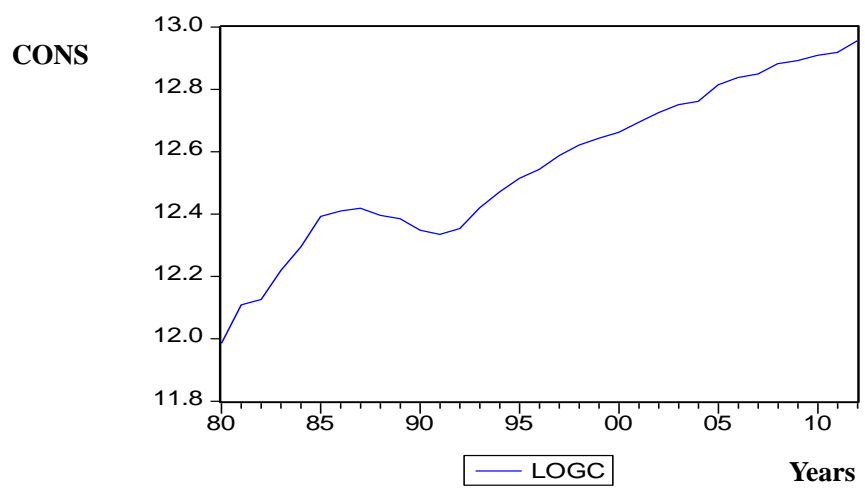

Figure 1a. Trends of consumption in Cameroon from (1980-2012)

Source: Computed by Authors using E-views 5.0.

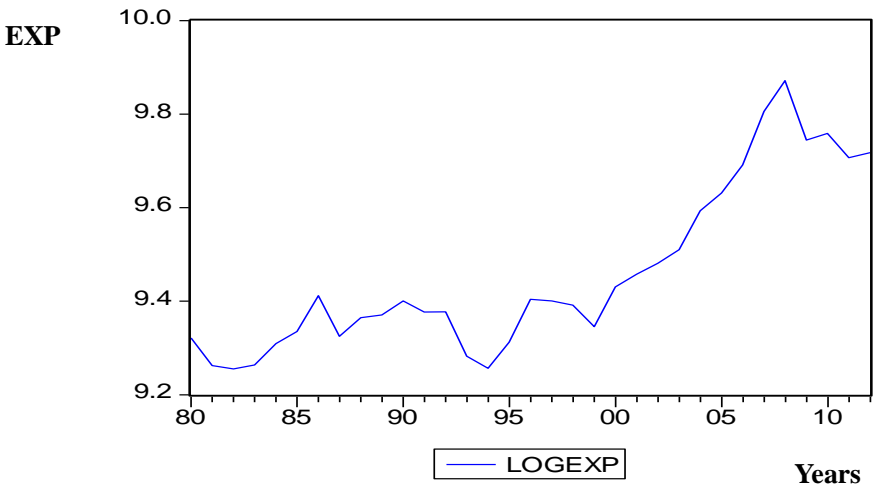

Figure 1b. Trends of exports in Cameroon from (1980-2012) 


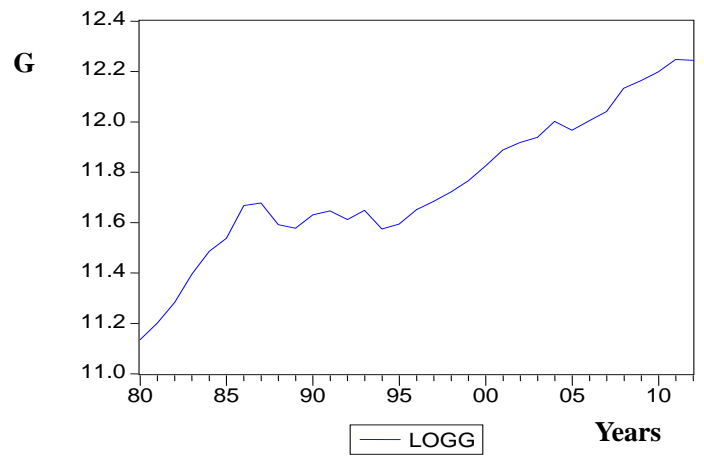

Figure 1c. Trends of government expenditure in Cameroon from (1980-2012) Source: Computed by Author using E-views 5.0).

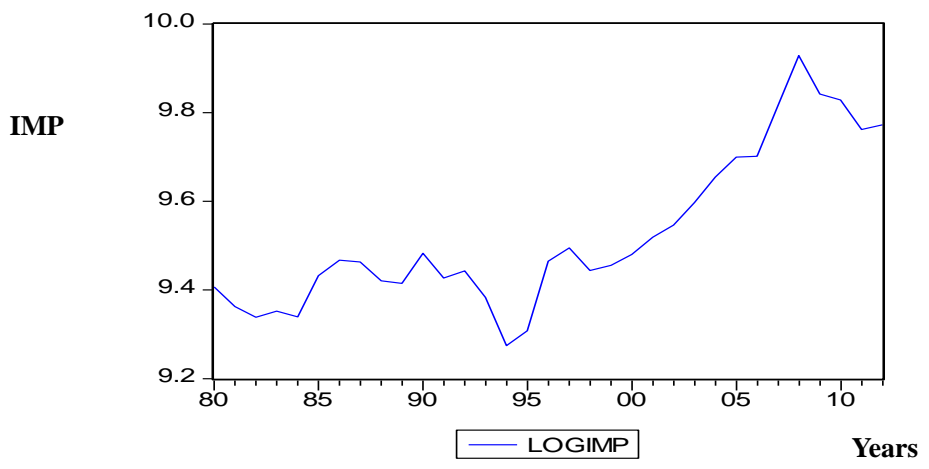

Figure 1d. Trends of imports in Cameroon from (1980-2012) Source: Computed by Authorr using E-views 5.0.

INV

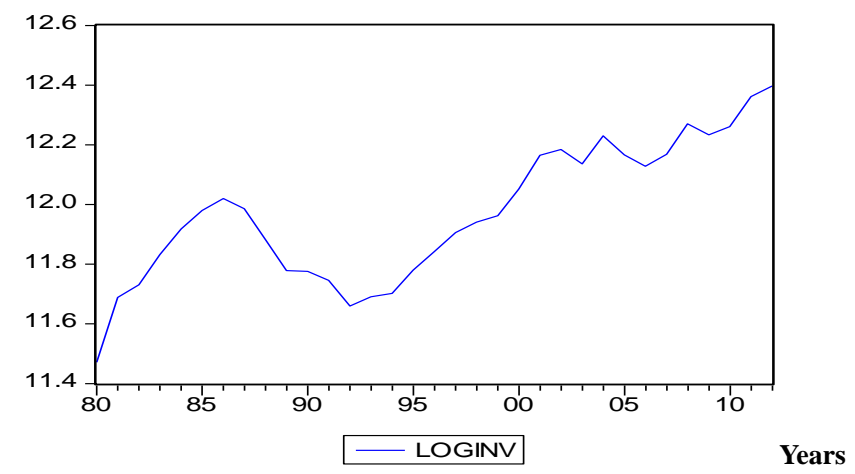

Figure 1e. Trends of investment in Cameroon from (1980-2012)

Source: Computed by Author using E-views 5.0.

\section{Appendix 2.}

Pairwise Correlation Matrix

\begin{tabular}{|c|c|c|c|c|c|c|c|}
\hline & LOGGDP & LOGC & LOGINV & LOGG & LOGEXP & LOGIMP & LOGREM \\
\hline LOGGDP & 1.000000 & & & & & & \\
\hline LOGC & 0.996941 & 1.000000 & & & & & \\
\hline LOGINV & 0.921359 & 0.897392 & 1.000000 & & & & \\
\hline LOGG & 0.979030 & 0.973264 & 0.909962 & 1.000000 & & & \\
\hline LOGEXP & 0.858213 & 0.855042 & 0.827148 & 0.886023 & 1.000000 & & \\
\hline LOGIMP & 0.838677 & 0.835467 & 0.831373 & 0.876268 & 0.985212 & 1.000000 & \\
\hline LOGREM & 0.744277 & 0.746125 & 0.746502 & 0.765066 & 0.888662 & 0.894371 & 1.000000 \\
\hline
\end{tabular}

Source: Computed by Author using E-views 5.0. 


\section{Appendix 3.}

\section{Augmented Dickey-Fuller (ADF) Unit Root Test}

\begin{tabular}{ccccc}
\hline Variable & Test Statistics at Level & Test Statistics after First Difference & Critical Value at 10\% & Degree Of Integration \\
\hline LOGGDP & -0.45 & -3.23 & -2.62 & $\mathrm{I}(1)$ \\
LOGC & -0.61 & -3.31 & -2.62 & $\mathrm{I}(1)$ \\
LOGINV & -0.44 & -2.94 & -2.62 & $\mathrm{I}(1)$ \\
LOGG & -1.16 & -3.28 & -2.62 & $\mathrm{I}(1)$ \\
LOGEXP & -0.70 & -3.61 & -2.62 & $\mathrm{I}(1)$ \\
LOGIMP & -0.89 & -4.61 & -2.62 & $\mathrm{I}(1)$ \\
LOGREM & -0.42 & -6.97 & -2.62 & $\mathrm{I}(1)$ \\
\hline
\end{tabular}

Source: Computed by Authors using results from E-views 5.0.

\section{Appendix 4.}

Variance Inflation Factor (VIF) Test for Multicollinearity

\begin{tabular}{ccc}
\hline Variable & VIF & $1 /$ VIF \\
\hline Logimp & 41.52 & 0.02 \\
logexp & 40.61 & 0.02 \\
Logg & 28.02 & 0.04 \\
Logc & 21.66 & 0.05 \\
Loginv & 6.40 & 0.16 \\
Logrem & 5.29 & 0.19 \\
Mean VIF & 23.92 & \\
\hline
\end{tabular}

Source: computed by Author using STATA 11.

\section{Copyrights}

Copyright for this article is retained by the author(s), with first publication rights granted to the journal.

This is an open-access article distributed under the terms and conditions of the Creative Commons Attribution license (http://creativecommons.org/licenses/by/4.0/). 